\title{
SYNERGISM AND ANTAGONISM OF INFLUENCE LOW DOSE RADIATION AND ENVIRONMENT ON HEALTH OF POPULATION IN UKRAINE
}

\author{
N.P.Dikiy ${ }^{1,2 *}$ E.P.Medvedeva ${ }^{1,2}$ \\ ${ }^{1}$ National Science Center "Kharkiv Institute of Physics and Technology", 61108, Kharkiv, Ukraine \\ ${ }^{2}$ V.N. Karazin Kharkiv National University, 6107\%, Kharkiv, Ukraine
}

(Received April 30, 2018)

\begin{abstract}
The genesis of carcinogenic diseases is characterized by a multifactor dependence. The effect of low dose radiation in combination with environmental factors has a significant number of features. It was studied the influence of certain features of the environment and the mental state of the person (affect) on the development of the incidence of carcinogenic diseases of the population in Ukraine. Given the various adverse environmental conditions, the effect of radiation in low doses can be enhanced or weakened. Synergism and antagonism of the effect of low dose radiation and environment on the health of the population are discussed.
\end{abstract}

PACS: 87.19.xj; 87.23.Cc; 87.53.Ay

\section{INTRODUCTION}

The study of the effect of low dose radiation on the human body in various natural conditions has important scientific significance and a number of important features. Several decades ago, we did not attach the necessary importance to the environmental threat. At present, the problem of environmental pollution is extremely urgent, leads to negative and irreversible changes in the state of human health.

In natural conditions, increased radioactivity acts as a radioecological factor. The interaction of this factor with the human body is complex, diverse and specific for each biogeocenosis. An increased radiation background for each biogeocenosis is created by a diverse composition and different concentration of radionuclides. Natural radioactive elements such as $\mathrm{U}$, Th, Ra, etc. have different physical characteristics and therefore create a complex spectrum of effects (short- and long-lived, solid and gaseous $\alpha, \beta$ and $\gamma$-emitters). As a result, a person undergoes combined external and internal irradiation with various radionuclides, which are accumulated in the organism.

But the most important is that in natural conditions, in addition to the action of low doses of the human organism, the effect of various environmental factors of non-radiation nature (temperature, humidity, and other habitats) is inevitably superimposed. As a rule, environmental factors are different in each biogeocenosis and therefore they are able to greatly enhance or weaken the biological effect of radiation factors. Even low levels of radiation $(\alpha, \beta$ and $\gamma$ - emitters), which are classified as low doses, can accumulate in environmental objects (soil, water, plants) [1-3] and subsequently have a negative impact on the human body. Therefore, the problem of low doses is actual and has not been sufficiently studied so far.

To assess the effect of low doses of radiation on the human organism, taking into account a complex of environmental factors, plus unbalanced nutrition, pathological processes, etc., it is necessary to develop methodological approaches [4]. One possible approach may be to estimate the balance of the mineral profile, which is the most sensitive and early diagnosed metabolic disturbance index. The determination of a group of biomarker elements in various functional systems of the human organism plays an important role in complex biochemical processes. It is known that macro- and microelements have a wide spectrum of synergistic and antagonistic relationships, on the one hand, and interaction with the signaling systems of the organism, on the other.

Pollution of the environment by heavy metals causes various toxic states in the human organism and develops an element deficit of such vital elements as $\mathrm{Mg}, \mathrm{Zn}, \mathrm{Fe}, \mathrm{Se}, \mathrm{Cu}$, etc. Heavy metals act as antagonists of these elements and can cause disturbances of the mineral balances. For example, a high content of $\mathrm{Pb}$ in hair in $70 \%$ of cases was combined with a low content of its antagonists $\mathrm{Zn}$ and Ca. This imbalance led to the appearance of various psychopathological disorders, neurosis-like syndrome, etc. Japanese scientist M. Nishimuta showed that the formation of intracellular deficiency of elements such as Ca, Zn, Se, Mn, Fe plays an important role

\footnotetext{
*Corresponding author E-mail address: ndikiy@kipt.kharkov.ua
} 
in the pathogenesis of diseases such as osteoporosis, Alzheimer's, various kinds of oncological diseases [5].

The established fact is that ionizing radiation, chemical carcinogens, oncogenic viruses, etc. are inhibitors of the body's immunological reactivity. In this case, the role of macro- and microelements in the regulation of antitumor immunity is extremely topical.

The central problem of modern oncology is the understanding and registration at the level of the mineral profile of the differences in the benign and malignant phenotype of the cell. In our works [6], a significant difference in the isotopic ratio of ${ }^{44} \mathrm{Ca} /{ }^{48} \mathrm{Ca}$ in normal, benign, malignant tissues and paratumour of the thyroid gland was shown (Fig.1). These results correlated with data on the level of free radical peroxide oxidation and the determination of highly reactive forms of oxygen (singlet oxygen ${ }^{1} \mathrm{O}_{2}$, hydroxyl radical $\mathrm{OH}^{-}$) at the level of cell membranes. As a result of exposure to various carcinogens, there is a disturbance in the balanced interaction of cellular components: between the number of oxidation substrates, oxygen concentrations, free radicals, antioxidants, reoxidation products, etc., relative to the rate of intensity of these processes. As a result, the cell passes into a different stable state.

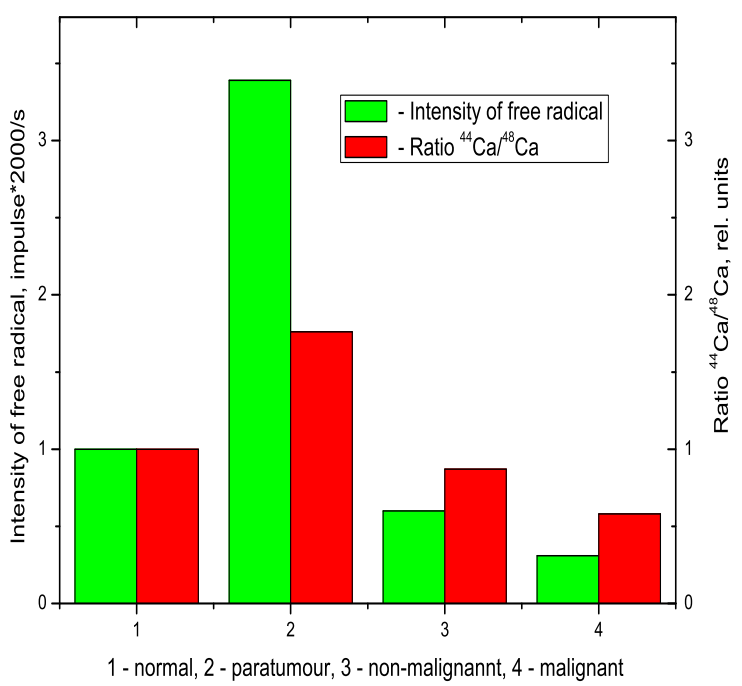

Fig.1. The intensity of induced chemiluminescence and isotopic ratio ${ }^{44} \mathrm{Ca} /{ }^{48} \mathrm{Ca}$ of homogenates of normal tissue, paratumour, non-malignant and malignant tissue

In addition, structures functioning in the cell membranes provide for the entry of $\mathrm{Ca}^{2+}$ into the cytoplasm along the gradient of its concentration ( $\mathrm{Ca}^{2+}$-channels), as well as the active $\mathrm{Ca}^{2+}$ transport system against the concentration gradient. The inconsistent functioning of the passive and active transport systems of $\mathrm{Ca}^{2+}$ through the plasma and intracellular membranes has been demonstrated $[7,8]$ on a statistically representative material in children (1012 years) with the initial stages of osteopenia and osteoporosis.

The lifestyle choices have a substantial effect on the risk of developing many common cancers. Increasing evidence indicates that comprehensive lifestyle changes could prevent cancer progression, and it is, therefore, crucial that public health measures are strengthened to better promote these interventions as part of a more holistic approach to cancer control. The interplay between immunity and diet, lifestyle, environmental, inflammatory and metabolomic factors, and the multi-biome (including viruses and protozoa) have important implications for prevention cancer [9].

The aim of the work is to assess the effect of low doses radiation in combination with environmental factors on the development of some pathologies of the population in Ukraine.

\section{MATERIALS AND METHODS}

This study was based on material sites of Medical Statistics of Ukraine, WHO and the statistics, which published in specialized journals of the inventory of cancer in Ukraine from 1976 to 2016 yr., and overall infant mortality, as well as statistics on Ukrstat air pollution. Also were used data from the State Forest Resources Agency of Ukraine.

Correlation and regression analysis were calculated by standard programs Mathcad 14, time series analysis was calculated by program Statistica 6.0.

\section{RESULTS AND DISCUSSION}

To understand the influence of factors of lowintensity radiation and environmental on the health of the population, various studies have been carried out. Radiosensitivity of biosystems to incorporated radionuclides $\left({ }^{137} \mathrm{Cs},{ }^{90} \mathrm{Sr},{ }^{235} \mathrm{U},{ }^{232} \mathrm{Th},{ }^{226} \mathrm{Ra},{ }^{40} \mathrm{~K}\right.$, etc.) in any case leads to the appearance of various changes at the cell level. At present, the carcinogenic effect of radiation is no longer in doubt. There is a fact of different mechanisms of formation of antitumor immunity in different individuals. As there is no doubt and the fact of different mechanisms of formation of antitumor immunity in different individuals. In the literary sources of recent decades, a lot of data has been accumulated on these questions, which are very diverse.

In recent years, there have been violations of evolutionary chemical equilibria on the earth and they are of a large regional or global nature. Such changes, especially clearly manifested in the last 50 years, are due to human activities. These include the drying up of forests surrounding the major industrial cities, the "bloom" of lakes and reservoirs, the waters of which acquire a specific smell and often become completely unsuitable for drinking, the deterioration of the quality of river waters which lost their former transparency and become more like gutters, number of birds that had previously filled the forests and meadows. Another visible sign of the negative changes was a sharp increase in allergic diseases in children. Physicians and toxicologists will add to this the "rejuvenation" of many dangerous diseases, 
changes in the physiological state and behavior of men - their feminization and demaskulination. Many diseases are now endemic, which in most cases is due to the presence of local sources of chemical pollution.

Behind all this lies the changes in chemical processes in the human environment and the natural environment. Most of them are associated with the inevitable in the conditions of continuous population growth with increasing human interference in natural biosphere processes by means of pollution of air, water and soil by various kinds of chemicals-waste products and synthesis products.

The most important biogenic component of the atmosphere is isoprene. It is believed that the emission of isoprene (like ethylene) increases many times under stress conditions - with tissue damage, during drought, etc. Also, we can definitely talk about the physiological and biocenotic functions of terpene hydrocarbons and their derivatives [10].

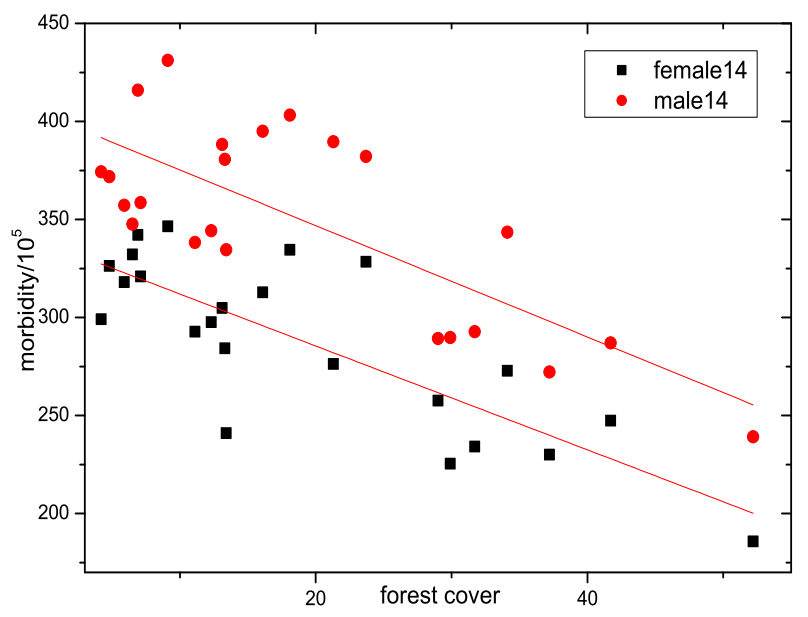

Fig.2. The incidence of cancer of man and women in Ukraine depending on the level of forest cover

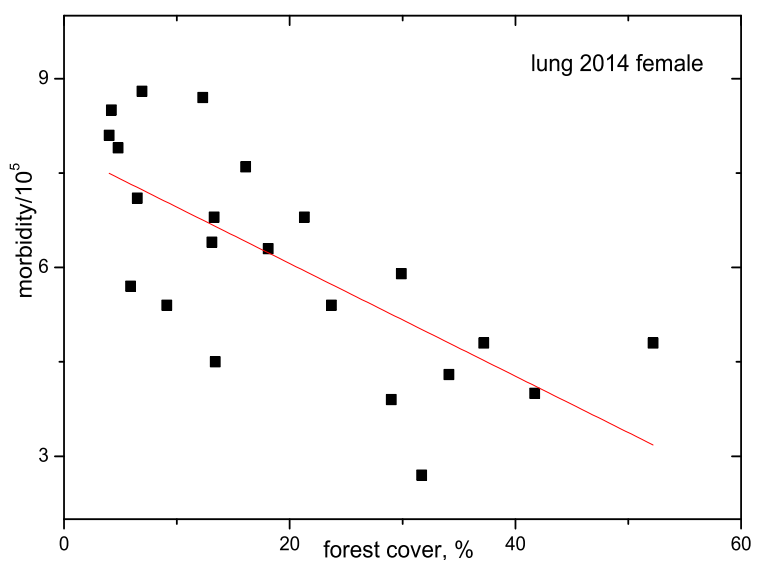

Fig.3. Morbidity of lung cancer of the population in Ukraine depending on the level of forest cover

The forest contributes greatly to the purification of atmospheric air from soot, smoke, and dust, prevents their further spread, weakens the effect of other harmful impurities. Green plantations can adsorb to
$70 \ldots 80 \%$ of aerosols and dust. The deciduous plantations, then coniferous-deciduous and, finally, coniferous, most effectively purify the air from unfavorable gaseous impurities. The willow, poplar and ash trees are able to absorb $200 \ldots 250$ grams of chlorine during the vegetative period, and shrubs $-100 \ldots 150 \mathrm{~g}$. It is established that the largest amount of lead was accumulated by leaves of horse chestnut, maple leaf: $600 \ldots 800$ and $300 \mathrm{mg} / \mathrm{kg}$ of dry matter, respectively.

Among volatile organic compounds are particularly important phytoncides - substances that are destructive of insects, bacteria, fungi, other microorganisms. Trees show the high activity of phytoncides in relation to air microorganisms, hemolytic streptococcus, Staphylococcus aureus and E. coli. Also, phytoncides are produced by juniper, walnut, dogrose, eucalyptus, etc. It is known that 1 ha of deciduous forest secures $2 \ldots 3 \mathrm{~kg}$ of volatile organic substances per day and 1 ha of coniferous - $5 \mathrm{~kg}$; 1 hectare of juniper bushes allocates $30 \mathrm{~kg}$ of phytoncides per day, which are sufficient for disinfecting the air of a large city. In the forest, $1 \mathrm{~m}^{3}$ of air contains, on the average, no more than 500 pathogenic bacteria, and in the city - more than 36 thousand. Volatile phytoncides of pine needles kill infusoria for $10 \ldots 15 \mathrm{~min}$, fir needles - after 5 and cedar - after 15 min, the aqueous solution from the needles of these trees kills protozoa during seconds.

It is established that most plants act selectively: phytoncides of oak leaves and poplar kill causative agents of dysentery, fir needles - diphtheria, pine - tuberculosis, etc. Phytoncides, allocated by forest plantations, have a beneficial effect on the nervous system of man. Phytoncides are activating the most important physiological processes in an organism. The phytoncides heal the air, and they are rightly called the vitamins of the atmosphere. It is noticed that in the young pine forest the air almost does not contain bacteria.

A great difficulty is finding out the patterns of interaction of the incidence of various forms of cancer in men and women, depending on environmental conditions, for example, the density of green plantations. In Fig. 2 shows the dependence of the incidence of various forms of cancer in men and women. It can be seen that oncological morbidity for men and women has the same tendency. The number of cases of cancer morbidity falls as there is a higher percentage of greening the environment. It is, of course, difficult to explain these results. But a similar trend is also found for individual types of cancer (lung cancer and breast cancer). In Fig.3 the dependence of cases of lung cancer morbidity on the density of green plantations is presented. The "modern tuberculosis", chronic bronchitis, tobacco smoke, asbestos, etc. stimulate the appearance of peripheral lung cancer very often. There is an opinion that $\sim 90 \%$ of lung cancer cases are caused by smoking. Among chronically ill with tuberculosis, the incidence of lung cancer has increased in few times [11]. The influence of exo-and endocarcinogens under conditions of hypoxia due to air pol- 
lution, especially in the urban zone, creates favorable conditions for the transformation of cells in the scar with impaired blood circulation. Scar develops local immunosuppression, and favorable conditions for the development of cancerous proliferative cells are created. Violation of the proliferation and differentiation of cells in the lung tissue leads to cancer. Thus, the complex relations exist between a human organism and environment. They include the reaction of an organism to tumoral processes and influence of a tumor to an organism. Only the immune system of the organism can react to the emergence of transformed cells in the organism. Environmental conditions play a key role and are the basis for protecting the organism from the development of the tumor process.

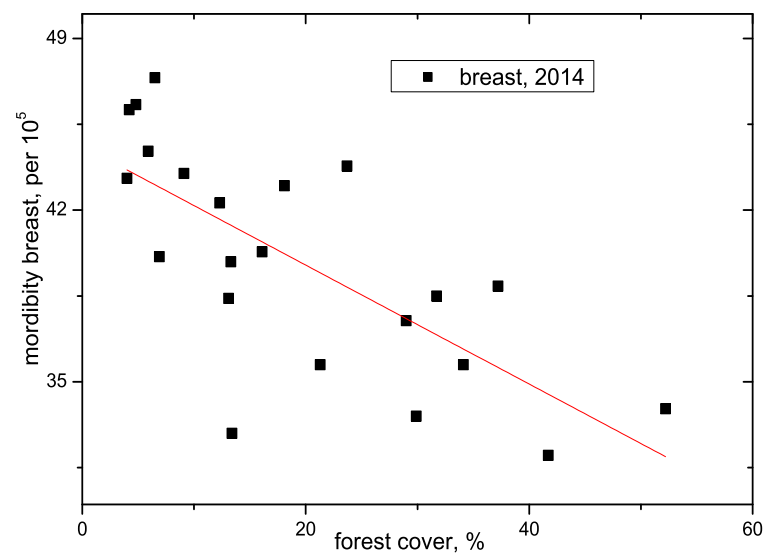

Fig.4. Morbidity of breast cancer of women living in Ukraine, depending on the level of forest cover

In Fig. 4 the dependence of cases of breast cancer depending on the density of green plantations is presented. There is a similar tendency. In this case, other mechanisms of interaction between the organism and the environment are included. Such interaction may be synergistic, additional, inhibitory or even lead to the formation of a new unknown effect. The organism's response to the action of exogenous and endogenous factors, apparently, leads to the activation of internal metabolic processes, with the formation of feedback. Violation of such autoregulatory mechanisms can lead to malignancy or other structural changes in the tissue or organ. It is known [12] that the mammary glands contain epidermal growth factor, which plays an important role in the process of carcinogenesis.

In Fig.5, the dependence of osteotropic cancers of women depending on the density of green plantations is shown. This dependence clearly demonstrates that this type of morbidity does not depend on this environmental factor. Osteotropic cancer is characterized by defects in fibrous structures, the main substance of connective tissue, "specific" metabolic reactions, and a peculiar microelement balance. The imbalance of elements such as $\mathrm{B}, \mathrm{Zn}, \mathrm{Ca}, \mathrm{Ni}$, which are involved in the exchange of connective tissue, is usually manifested by the excessive accumulation of Sr. Stable $\mathrm{Sr}$ with its high intake into the organism causes dam- age and deformation of the joints and other disorders that can develop malignant tumors of bones. The literature data indicate that $\mathrm{Sr}$ is a biologically important element that plays an important role in the processes of bone formation with insufficient $\mathrm{Ca}$ in the environment. The increased content of stable $\mathrm{Sr}$ is relevant for large industrial regions. Sr initially compensates for $\mathrm{Ca}$ in the bones, and its further accumulation leads to the development of osteopenic disorders, which are often detected in almost $93 \%$ of osteotropic cancers. The main factors in the appearance of the tumor process are, apparently, calcium interactions, in particular, an increase in the concentration of $\mathrm{Ca}^{2+}$ on the surface of cells and an increase in the cellular charge.

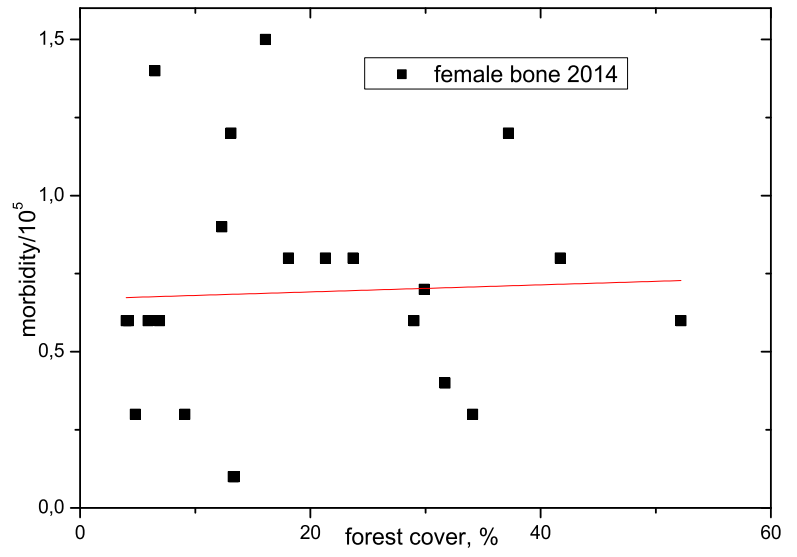

Fig.5. Incidence of cancer of the bones of women living in Ukraine, depending on the forest cover

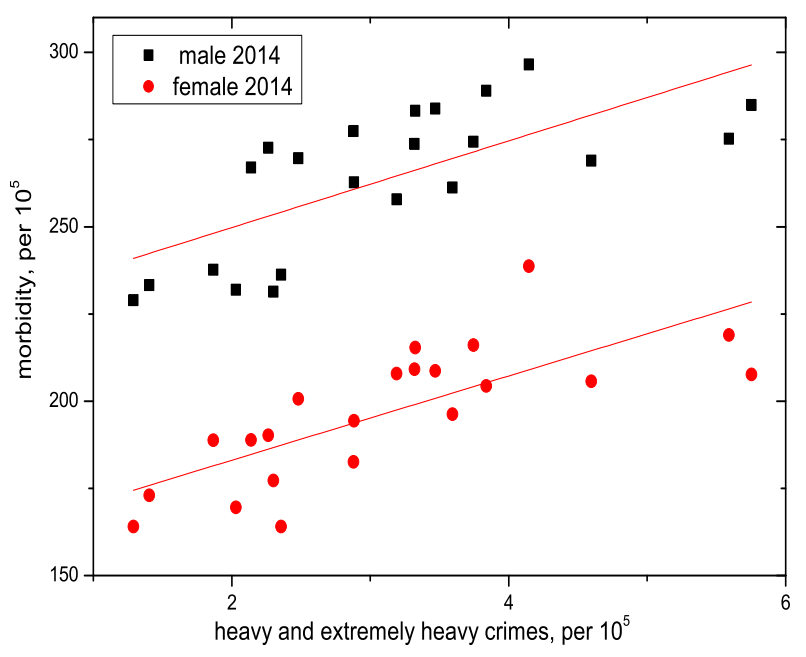

Fig.6. Morbidity of cancer diseases of the population of Ukraine depending on a grave and extremely serious crimes

Also, environmental pollution affects mental illness. It is known that the effects of air pollution on cardiovascular health and lung diseases like asthma are well established, but this area of brain health is a newer area of research. The University of Washington studied for a direct connection between toxic air and psychological distress [13]. Especially dangerous crimes, apparently, can also be attributed to mental 
illnesses. In this regard, it should be noted that diseases of cancer and particularly dangerous criminal offenses have a common cause, which, apparently, is due to the impact of adverse factors on a central nervous system. Air pollution, too, has been associated with behavior changes - spending less time outside, for instance, or leading a more sedentary lifestyle that can be related to psychological distress or social isolation.

One of the reasons for the growth of mental illnesses is intoxication (or autointoxication), caused by compounds that pollute the environment. Characteristic for the biochemical syndrome of intoxication are violations of biochemical neutralizing syntheses - the synthesis of rhodanous compounds, of glutamine, the synthesis of paired glucuronic and esterosulfuric acids, of methylation products. With the syndrome of intoxication, many detoxification products are formed (detoxification). However, with prolonged intoxication, their synthesis begins to decrease (damage to the liver and other organs, where detoxification occurs), and the amount of toxic substances increases.

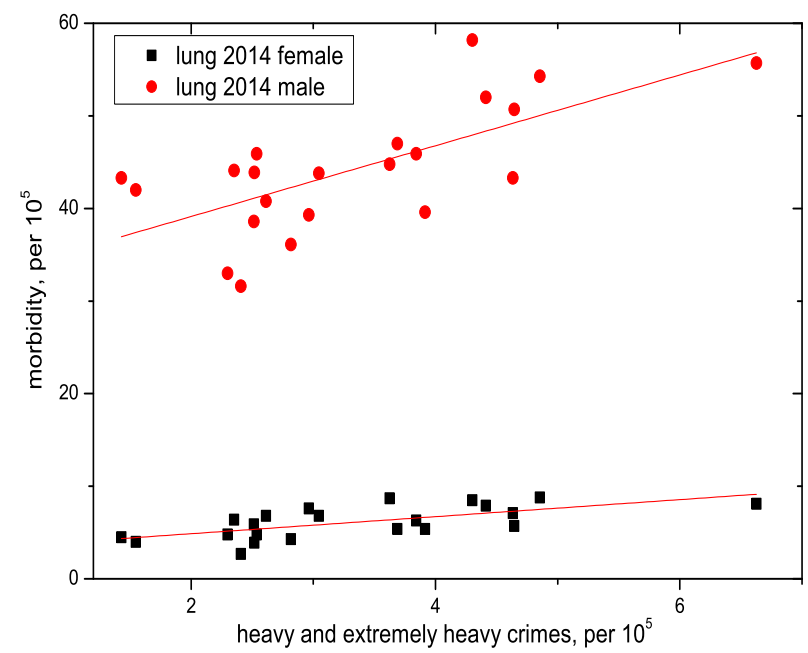

Fig.7. Morbidity of lung cancer in Ukraine, depending on a grave and extremely serious crimes

Macro and micro elements are also biologically active ingredients of the nervous tissue and the chemical basis of the central nervous system. The disruption of the exchange of macro- and microelements ( $\mathrm{Na}, \mathrm{Ca}$, $\mathrm{K}, \mathrm{Al}, \mathrm{Mg}, \mathrm{Zn}, \mathrm{Se}, \mathrm{Mn}, \mathrm{Co}, \mathrm{Cu}$ ) plays an important role in the pathogenesis of the neurological profile. Recently, a lot of information has appeared on the significance of $\mathrm{Mg}$ in the functioning of the nervous system. Disorders of higher nervous activity are accompanied by changes in the transmembrane transport of ions, primarily $\mathrm{Mg}$. Deficiency of $\mathrm{Mg}$ leads to behavioral disorders, hyperactivity, impulsivity. In a state of stress, the excretion of $\mathrm{Mg}$ from the organism by the hormones adrenaline and cortisone increases. The Mg deficiency correlates with an excess of other neurotoxic elements $\mathrm{Pb}, \mathrm{Al}, \mathrm{Cd}, \mathrm{Ni}, \mathrm{Cr}$, Se. At the same time, the content of $\mathrm{Fe}, \mathrm{Na}, \mathrm{Cu}$ in concentrations exceeding the physiological threshold, acquire the properties of neurotoxic elements. Psychopathic conditions are often accompanied by the presence of toxic products such as ammonia, uric acid. The disturbance of oxidation-reduction processes is an important link in various psychopathological symptoms. In general, this may be due to the restriction of $\mathrm{O}_{2}$ intake. Oxygen starvation refers to significant disorders of the central nervous system. N.M. Emanuel [14] showed that during oxidation-reduction reactions various inhibitors appear in the form of free radical compounds $\left(\mathrm{OH}^{-}, \mathrm{H}_{3} \mathrm{O}^{+}, \mathrm{H}_{2} \mathrm{O}_{2}\right)$, i.e. the same radicals as under radiation irradiation. These radicals have an inhibitory effect on oxidative enzymes catalase, peroxidase, dehydrogenase, and oxidase. This group of enzymes contains $\mathrm{Fe}, \mathrm{Cu}$ in its structure.

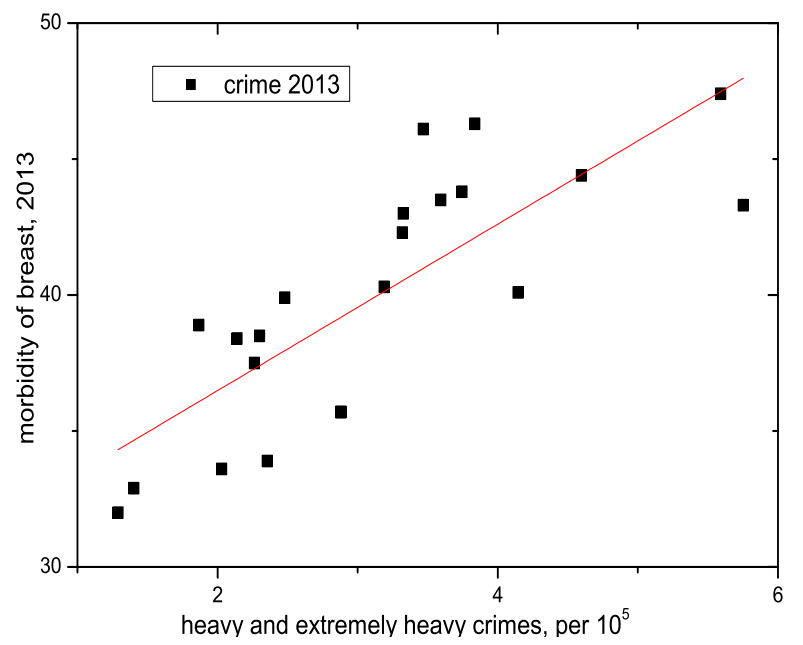

Fig.8. Morbidity of breast cancer of the Ukrainian population, depending on a grave and extremely serious crimes

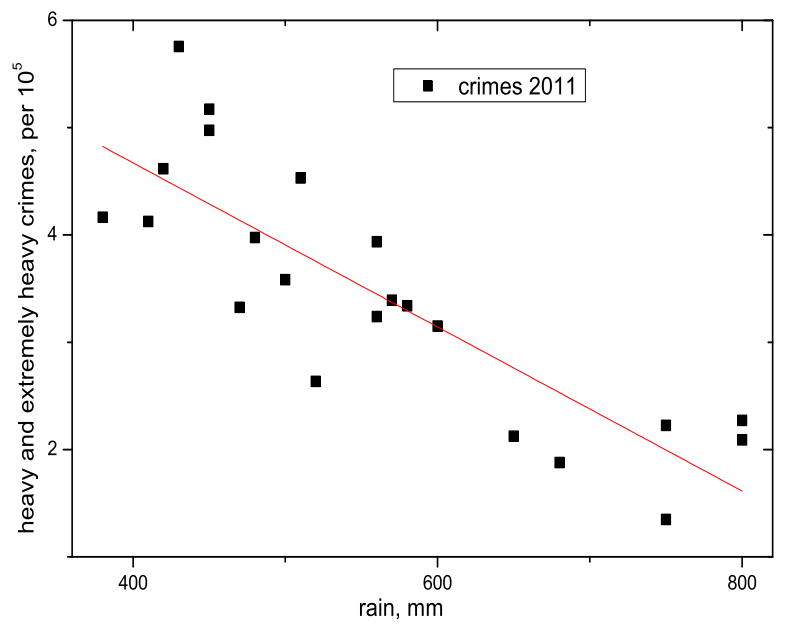

Fig.9. The number of heavy and extremely heavy crimes in Ukraine, depending on annual precipitation

We can not give a correct assessment of the role of these disorders in the pathogenesis of mental disorders. But, apparently, we can say that in the organism of such individuals there are grounds by which 
psychopathological manifestations arise [15-17]. Psychoemotional states of a healthy person and a patient with mental illnesses cannot be explained solely by physiological concepts. But the formation of a personality under conditions of a certain psychological situation and social environment ultimately leads some individuals to borderlines.

Figs.6-8 shows the dependence of the general incidence of cancer in men and women, lung cancer, and breast cancer versus heavy and extremely heavy crimes, respectively. It can be seen that with the increase in heavy and extremely heavy crimes, the incidence of cancer is also increasing. The effect of toxic compounds can be confirmed by Fig.9, which shows a decrease in heavy and extremely heavy crimes with an increase in annual precipitation. Rains "scavenge" away toxic compounds from the air.

These results confirm the complexity of the possibility of interpretation in these pathological conditions. But one can definitely say that these pathological conditions are one of the main national problems [17-19].

\section{CONCLUSIONS}

A methodological approach was developed to assess the effect of low radiation doses and adverse environmental factors on the basis of biomarker determination-the content of the mineral profile and the level of products of a free radical nature.

The changes in chemical processes in the human environment and the environment take place on the earth. Most of them are associated with increasing human interference in natural biosphere processes by means of pollution of air, water, and soil by various kinds of chemicals. Environmental pollution affects mental illness. Also, especially dangerous crimes, apparently, can be attributed to mental illnesses. In this regard, it should be noted that diseases of cancer and particularly dangerous criminal offenses have a common cause, which, apparently, is due to the impact of adverse factors on the higher nervous system.

Pollution of the environment significantly affects the health of the population. Therefore, differences in the level of pollution cause different degrees of cancer in various regions in Ukraine.

\section{References}

1. N.P. Dikiy, A.N. Dovbnya, Yu.V. Lyashko, et al. Radionuclide accumulation by objects of ecosystem (93) // PAST. Ser.: "NPI". 2014, N5(63), p. $45-49$.

2. N.P. Dikiy, A.N. Dovbnya, Yu.V. Lyashko, et al. Radionuclide biosorption by the aquatic plants of Pistia Stratiotes (93) // PAST. Ser.: "NPI". 2014, N5(63), p.50-53.

3. N.P. Dikiy, Yu.V. Lyashko, D.S. Katalevska, et al. Anthropogenic radionuclide and trace elements of soil and celandine in Kharkiv city (93) // PAST. Ser.: "NPI". 2014, N5(63), p.54-58.

4. N.P. Dikiy, A.N. Dovbnya, E.P. Medvedeva. Low doses of radiation: epidemiological investigations (85) // PAST. Ser.: "NPI". 2013, N3(60), p.220230 .

5. M. Nishimuta. The concept of intracellular-, extracellular- and bone minerals // BioFactors. 2000, v.12, N1-4, p.35-38.

6. N.P. Dikiy, A.N. Dovbnya, N.V. Krasnoselsky, et al. Determination of isotope ratio calcium by gamma activation analysis and free radical oxidation of lipids in normal and cancerous tissues of thyroid gland // PAST. Ser.: "NPI". 2000, N2(36), p.62-63.

7. T.V. Frolova, N.P. Dikiy, E.P. Medvedeva. Application of the gamma-activation method to the study of the age-related dynamics of the content of certain elements in the hair of children // Bulletin KNU. Ser.: "phys., nucl., field". 2007, N784, is.4(36), p.67-73 (In Russian).

8. T.V.Frolova, N.P. Dikiy, E.P. Medvedeva, O.V. Ohapkina. Features of the isotope ratio of ${ }^{44} \mathrm{Ca} /{ }^{48} \mathrm{Ca}$ in children living in the industrial region of Kharkiv region // Ukr. Med. Almanac. 2005, v.8, N2, p.192-195 (In Russian).

9. E.M. Jaffee, C.V. Dang, D.B. Agus, et al. Future cancer research priorities in the USA: a Lancet Oncology Commission // The Lancet Oncology Commission. 2017, v.18, p.653-706.

10. K.N.Zelenin. Organic substances of the atmosphere // Soros general education magazine. 1998, N4, p.39-44 (In Russian).

11. Yu.N. Korystov. Physiological and reparative tissue regeneration is the main factor of oncogenesis // Adv. Mod. Biol. 1993, N5, p.606-625 (In Russian).

12. W.J.Storkus, J.R. Dawson. Target structures involved in natural killing // Crit. Rev. Immunol. 1991, v.10, p.393-416.

13. V. Sassa, N. Kravitz-Wirtzb, S.M. Karceski, et al. The effects of air pollution on individual psychological distress // Health \& Place. 2017, v.48, p.72-79.

14. N.M. Emanuel. Kinetics experimental tumoral processes, M.: "Science", 1977, 419p. (in Russian).

15. J.S. Fowler, N.D. Volkow, G.-J. Wang, et al. PET and Drug Research and Development // J. Nucl. Med. 1999, v.40, p.1154-1163.

16. N.D. Volkow, M. Morales1. The Brain on Drugs: From Reward to Addiction // Cell. 2015, v.162, p.712-725. 
17. N.D. Volkow, R.A. Wise, R. Baler. The dopamine motive system: implications for drug and food addiction // Nature Reviews Neuroscience. 2017, v.18, p.741-752.

18. G.W. Evans. The Built Environment and Mental Health // J. Urban Health: Bull. New York
Academy of Medicine Health, 2003, v.80, p.536555.

19. M.L. Block, A.Elder, R.L.Auten, et al. The Built The Outdoor Air Pollution and Brain Health Workshop Environment // Neurotoxicology. 2012, v.33(5), p.972-984.

\title{
СИНЕРГИЗМ И АНТАГОНИЗМ ВЛИЯНИЯ МАЛЫХ ДОЗ РАДИАЦИИ И ОКРУЖАЮЩЕЙ СРЕДЫ НА ЗДОРОВЬЕ НАСЕЛЕНИЯ УКРАИНЫ
}

\author{
Н. П. Дикий, Е.П. Медведева
}

Возникновение канцерогенных заболеваний характеризуется многофакторной зависимостью. Влияние малых доз радиации в сочетании с факторами окружающей среды имеет значительное количество особенностей. Было изучено влияние некоторых особенностей окружающей среды и психического состояния человека (аффекта) на развитие заболеваемости канцерогенными болезнями населения Украины. Выявлена зависимость заболеваемости канцерогенными болезнями от природных и бытовых условий населения. Обсуждаются также синергизм и антагонизм влияния малых доз радиации и различных экологических факторов на рассматриваемые параметры.

\section{СИНЕРГІЗМ І АНТАГОНІЗМ ВПЛИВУ МАЛИХ ДОЗ РАДІАЩІї ТА НАВКОЛИШНЬОГО СЕРЕДОВИЩА НА ЗДОРОВ'Я НАСЕЛЕННЯ УКРАЇНИ}

\section{М. П. Дикий, О.П. Медведева}

Виникнення канцерогенних захворювань характеризується багатофакторною залежністю. Вплив малих доз радіації в поєднанні з факторами навколишнього середовища має значну кількість особливостей. Було вивчено вплив деяких особливостей навколишнього середовища і психічного стану людини (афекту) на розвиток захворюваності канцерогенними хворобами населення України. Виявлено залежність захворюваності канцерогенними хворобами від природних і побутових умов населення. Обговорюються також синергізм і антагонізм впливу малих доз радіації і різних екологічних факторів на розглянуті параметри. 